\title{
KNOWLEDGE MANAGEMENT DAN KINERJA ORGANISASI SEKTOR PUBLIK: STUDI EMPIRIS PADA ENTITAS AKUNTANSI DI INDONESIA
}

Muhammad Farid

Direktorat Akuntansi dan Pelaporan Keuangan

Y. Anni Aryani

Universitas Sebelas Maret

Alamat Korespondensi: farid.muhammad83@gmail.com

\section{INFORMASI ARTIKEL}

Diterima Pertama

18 Mei 2016

Dinyatakan Diterima

30 Agustus 2016

KATA KUNCI:

Performance of accounting entities,

Knowledge Management Enablers,

Structural Equation Modelling (SEM).

KLASIFIKASI JEL:

M400.

\begin{abstract}
ABSTRAK
This study aims to investigate the effect of knowledge management enablers on the performance of accounting entities in Indonesia. Knowledge management enablers consist of ICT know-how and skills, job training, job rotation, knowledge management technology and knowledge sharing. The sample of the study comprises 229 accounting entities in Indonesia. Data was collected by online survey method and analyzed using AMOS 22 software for structural equation modelling (SEM). The results show that four knowledge management enablers, namely ICT know-how and skills, job training, knowledge management technology and knowledge sharing, have significant influences on the performance of accounting entities. Meanwhile, job rotation does not affect the performance of the accounting entities.
\end{abstract}

Penelitian ini bertujuan untuk mengetahui pengaruh knowledge management enablers terhadap kinerja entitas akuntansi di Indonesia. Knowledge management enablers dalam penelitian ini terdiri dari ICT knowhow dan skills, job training, job rotation, knowledge management technology, dan knowledge sharing. Sampel dalam penelitian ini adalah 229 penyusun laporan keuangan pada entitas akuntansi di Indonesia. Data dikumpulkan dengan metode survei online. Data dalam penelitian ini dianalisis menggunakan Structural Equation Modelling (SEM) dengan software AMOS 22. Hasil penelitian menunjukkan bahwa empat knowledge management enablers yaitu ICT know-how dan skills, job training, knowledge management technology, dan knowledge sharing berpengaruh signifikan terhadap kinerja entitas akuntansi di Indonesia. Sementara itu, satu knowledge management enablers yaitu job rotation tidak berpengaruh terhadap kinerja entitas akuntansi di Indonesia. 


\section{PENDAHULUAN}

\subsection{Latar Belakang}

Undang-undang nomor 25 tahun 2009 tentang Pelayanan Publik memberikan amanat kepada instansi pemerintah untuk menyelenggarakan pelayanan publik yang baik kepada masyarakat. Undang-undang tersebut mempunyai tujuan memberikan kepastian hukum kepada masyarakat dalam penyelenggaraan pelayanan publik. Ombudsman adalah lembaga yang berdasarkan undang-undang mempunyai kewenangan dalam pengawasan terhadap pelaksanaan pelayanan publik di Indonesia.

Ombudsman Republik Indonesia (ORI) mencatat bahwa keluhan masyarakat yang berkaitan dengan penyimpangan penyelenggaraan pelayanan publik pada tahun 2013 meningkat hampir 2 kali lipat dibandingkan tahun 2012. Ombudsman menerima 4.359 laporan masyarakat pada tahun 2013, yang mana laporan tersebut meningkat 97,3\% dibandingkan tahun 2012, yaitu sebanyak 2.209 aduan. Pemerintah daerah berada di urutan pertama dalam jumlah keluhan yang diterima Ombudsman, yakni 41,8\%. Kepolisian berada di peringkat kedua dengan $13,3 \%$, disusul oleh instansi pemerintah/ kementerian sebesar $10,7 \%$, dan Badan Pertanahan Nasional (BPN) sebesar 6,8\%. Hal ini mengindikasikan bahwa masyarakat sudah peduli dengan hak untuk mendapatkan pelayanan publik yang baik.

Banyaknya keluhan pelayanan publik sebagaimana dilaporkan oleh Ombudsman tersebut merupakan bukti bahwa pelayanan publik di Indonesia masih buruk. Kinerja yang tidak maksimal tersebut harus diperbaiki dan ditingkatkan demi kepentingan rakyat. Peningkatan kerja tidak akan terwujud apabila tidak ada pengelolaan manajemen yang baik. ${ }^{1}$ Manajemen pengetahuan (knowledge management) merupakan sebuah alat bagi manajemen dalam mengelola organisasi yang menekankan pentingnya ilmu pengetahuan untuk menentukan keunggulan kompetitif sebuah organisasi. Knowledge management (KM) merupakan sebuah alat dalam pengelolaan manajemen yang dapat digunakan untuk meningkatkan kinerja organisasi. ${ }^{2}$ Keberhasilan

1 Normala Dewi Anggraini, Pengaruh Praktek Knowledge Management Terhadap Kinerja Organisasi, Skripsi Tidak Dipublikasikan, (Semarang: Universitas Diponegoro, 2013).

2 Siong Shoy Chong et al., "KM Implementation in a Public Sector Accounting Organization: An Empirical Investigation", The Journal of implementasi KM pada entitas akuntansi dapat mendukung terciptanya pelaporan keuangan yang akurat dan tepat waktu serta dapat memenuhi persyaratan peraturan. ${ }^{3}$

Chong et al. (2011) dalam penelitiannya berhasil membuktikan bahwa KM enablers sangat signifikan memengaruhi kinerja organisasi sektor public. ${ }^{4} \mathrm{KM}$ enablers dalam penelitian ini terdiri dari 5 hal, yaitu ICT know-how \& skill, job training, job rotation, KM technology, dan knowledge sharing. Kelima KM enablers tersebut digunakan dalam penelitian ini dengan tujuan untuk mengetahui apakah kinerja pelayanan instansi pemerintah meningkat apabila kelima KM enablers tersebut diimplementasikan dengan baik.

Perbedaan penelitian ini dengan Chong et al. (2011) adalah dari sisi lokasi penelitian, penelitian Chong et al. (2011) tersebut dilaksanakan di Kementerian Keuangan Malaysia dengan responden para akuntan yang bekerja di dalamnya. Sedangkan penelitian ini lebih fokus pada entitas akuntansi sebagaimana didefinisikan dalam Peraturan Pemerintah No. 71 tahun 2010 tentang Standar Akuntansi Pemerintah. ${ }^{5}$

Definisi entitas akuntansi menurut PP 71 tahun 2010 tentang Standar Akuntansi Pemerintah adalah badan atau organisasi yang menerima dan mengelola dana APBN serta wajib menyusun laporan keuangan atas pengelolaan dana APBN tersebut. Entitas akuntansi dapat juga disebut sebagai satuan kerja atau instansi pemerintah yang tersebar di seluruh Indonesia. Entitas akuntansi yang menghasilkan laporan keuangan berperan penting dalam akuntabilitas kinerja instansi pemerintah. Laporan keuangan yang diterbitkan merupakan salah satu bentuk pelayanan publik yang digunakan untuk menilai kinerja instansi pemerintah.

\section{KERANGKA TEORI DAN PENGEM- BANGAN HIPOTESIS}

Masalah keagenan antara principal dan agent sebagaimana dicetuskan oleh Jensen dan Meckling (1976), akan selalu terjadi di sebuah perusahaan

Knowledge Management, 2011, Vol.15, No.3, hlm. 457-512.

3 B. Whitmore dan J.A Albers, "Knowledge Management in an Accounting Organization". The Journal of Knowledge Management Practice, 2006, Vol. 7, No. 4.

4 Chong et al., Loc.Cit., hlm. 467-512.

5 Ibid. 
atau organisasi. 6 Scott (2009) mengasumsikan antara manajer dan investor mempunyai sifat rasional dan akan memilih kebijakan akuntansi untuk kepentingan masing-masing. ${ }^{7}$ Oleh karena itu, manajer mempunyai kecenderungan untuk memaksimalkan utilitas harapan yang bersifat oportunis. Sifat oportunis tersebut dipengaruhi oleh tiga kondisi, yaitu bonus plan, debt covenant dan political cost. ${ }^{8}$ Untuk mengatasi masalah tersebut, principal dapat mengeluarkan monitoring cost untuk mengurangi tindakan menyimpang yang dilakukan agen. ${ }^{9}$ Salah satu bentuknya meliputi audit, sistem pengendalian formal, pembatasan anggaran dan sistem kompensasi insentif.

Principal di dalam sektor publik sering diartikan sebagai rakyat, sedangkan agen adalah pemerintah sebagai eksekutif. ${ }^{10}$ Pertanggungjawaban dari pemerintah kepada rakyat diwujudkan dalam bentuk laporan keuangan pemerintah. ${ }^{11}$ Laporan keuangan itulah yang akan dijadikan sumber informasi oleh rakyat untuk menilai kinerja pemerintah sebagai agen

6 Michael C. Jensen dan William H. Meckling, "Theory of The Firm: Managerial Behavior, Agency Cost and Ownership Structure", The Journal of Financial Economics, 1976, Vol. 3, No. 4, hlm. 305-360.

7 William R Scott, Financial Accounting Theory. Edisi Kelima, (Toronto: Pearson, 2009).

8 R.L Watts dan J.L Zimmerman, "Positive Accounting Theory: a Ten Years Perspective", The Accounting Review, 1990, Vol. 65, No. 1, hlm. $131-156$.

9 Michael C. Jensen dan William H. Meckling., Loc.Cit.

10 Syukriy Abdullah, dan Jhon Andra Asmara, "Perilaku Oportunistik Legislatif dalam Penganggaran Daerah", (Padang: Simposium Nasional Akuntansi IX, 2006); Nurul Latifah, "Adakah Perilaku Oportunistik dalam Aplikasi Agency Theory di Sektor Publik?", Fokus Ekonomi, 2010, Vol 5, No. 2, hlm. 85-94; Abdul Halim dan Syukriy Abdullah, "Hubungan dan Masalah Keagenan di Pemerintah Daerah". Jurnal Akuntansi Pemerintahan, 2006, Vol. 2. No. 1, hlm. 53-64.

11 Amiruddin Zul Hilmi dan Dwi Martani, “Analisis Faktor-Faktor Yang Mempengaruhi Tingkat Pengungkapan Laporan Keuangan Pemerintah Provinsi", (Banjarmasin: Simposium Nasional Akuntansi XV, 2012). dari rakyat. ${ }^{12}$ Berdasarkan permasalahan hubungan keagenan yang dijelaskan di atas, penelitian ini mencoba mengoptimalkan variabelvariabel KM enablers untuk meningkatkan kinerja entitas akuntansi di Indonesia.

Sejak pengetahuan dikategorikan sebagai aset intelektual organisasi, ${ }^{13} \mathrm{KM}$ telah menjadi praktik standar dalam suatu organisasi di seluruh dunia. ${ }^{14}$ Pengertian KM adalah proses menciptakan, menangkap dan menggunakan pengetahuan untuk meningkatkan kinerja pada organisasi, bukan individu. ${ }^{15}$ Sementara itu, Syed-Ikhsan dan Rowland (2004) mendefinisikan KM sebagai upaya sistematis dan terorganisasi untuk menggunakan pengetahuan dalam organisasi dengan tujuan memberikan layanan kepada masyarakat dan meningkatkan kinerja. ${ }^{16}$

\subsection{Kinerja Organisasi dan ICT know-how Skills}

ICT know-how \& skills berhubungan positif signifikan dengan kinerja transfer pengetahuan organisasi sektor publik di Malaysia (Salleh et al., 2012; Syed-Ikhsan dan Rowland, 2004). Namun

12 Arja Sadjiarto, "Akuntabilitas dan Pengukuran Kinerja Pemerintah", Jurnal Akuntansi \& Keuangan, 2000, Vol. 2, No. 2, hlm. 138 - 150; Elvira Zeyn, "Pengaruh Good Governance dan Standar Akuntansi Pemerintahan terhadap Akuntabilitas Keuangan dengan Komitmen Organisasi Sebagai Pemoderasi”, Jurnal Reviu Akuntansi dan Keuangan, 2001, Vol. 1, No. 1, hlm. 21-37.

13 M.S. Bogdanowicz dan E.K. Bailey, "The Value of Knowledge and the Values of the New Knowledge Worker: Generation X in the New Economy". The Journal of European Industrial Training, 2002, Vol. 26, No. 2/3/4, hlm. 125139.

14 H-D. Evers dan S. Gerke, "Knowledge is Power; Experts a Strategic Group", Working Paper Series, Center for Development Research University of Bonn, 2005.

15 J.S. Edwards, P.M. Collier, dan D. Shaw, Knowledge Management and Its Impact on the Management Accountant. (London: The Chartered Institute of Management Accountants (CIMA), 2005).

16 SoS. Syed-Ikhsan, dan Fytton Rowland, "Knowledge Management in Public Organization: A Study on the Relationship between Organizational Elements and the Performance of Knowledge Transfer", The Journal of Knowledge Management, 2004, Vol. 8. No 2, hlm. 95-111. 
Chong et al., (2011) menemukan bahwa ICT knowhow \& skills berhubungan negatif signifikan dengan kinerja organisasi. Sementara itu, literatur menunjukkan bahwa semakin banyak pelatihan yang diberikan untuk meningkatkan keterampilan teknologi informasi dan komunikasi, individu akan semakin memanfaatkan alat teknologi informasi dan komunikasi. ${ }^{17}$ Selanjutnya, pengetahuan dan keterampilan tersebut dapat ditransfer dan dibagikan ke dalam dan ke luar organisasi. ${ }^{18}$ Semakin organisasi mempunyai pengetahuan dan keterampilan, maka secara logika organisasi akan mempuyai kinerja yang lebih baik daripada organisasi yang mempunyai sedikit pengetahuan. Oleh karena itu, dapat dihipotesiskan bahwa:

$\mathbf{H}_{1}$ : Terdapat hubungan positif antara ICT knowhow and skills dengan kinerja entitas akuntansi.

\subsection{Kinerja Organisasi dan Job Training}

Pelatihan membuat karyawan merasa bahwa mereka adalah bagian dari organisasi. Tujuan dari pelatihan kerja (job training) adalah mengembangkan pengetahuan karyawan yang dibutuhkan untuk melaksanakan pekerjaan. ${ }^{19}$ Selain itu, pelatihan menciptakan pengembangan profesional dan meningkatkan keterampilan karyawan. Pengetahuan yang diperoleh karyawan melalui pelatihan kerja memungkinkan untuk menerjemahkan pengetahuan ke dalam rutinitas organisasi, kompetensi, deskripsi pekerjaan, proses bisnis, rencana, strategi, dan budaya. ${ }^{20}$

17 Siong Shoy Chong, et al., "KM Implementation in a Public Sector Accounting Organization: An Empirical Investigation", The Journal of Knowledge Management, 2011, Vol. 15, No. 3, hlm. 457-512; Kalsom Salleh, et al., "Learning and Knowledge Transfer Performance among Public Sector Accountants: An Empirical Survey". Knowledge Management Research and Practice, 2012, Vol. 10. No. 2, hlm. 164-174.

18 Kalsom Salleh, et al., "KM Strategy for EGovernment: An Exploratory Study of Local Authorities in Malaysia", (Working-Paper, University Technology Mara), 2006; Siong Shoy Chong, et al., "KM Implementation in a Public Sector Accounting Organization: An Empirical Investigation", The Journal of Knowledge Management, 2011, Vol. 15, No. 3, hlm. 457-512.

19 Larry. W Carlile, "Knowledge Management and Training: The Value of Collaboration". Performance Improvement, 2002, Vol. 41. No. 4, hlm. 37- 43.

20 CW. Holsapple dan M. Singh, "The Knowledge Chain Model: Activities for Competitiveness", Handbook on Knowledge Management 2:
Karyawan dengan kompetensi yang lebih banyak akan lebih dapat meningkatkan kinerja organisasi daripada karyawan yang mempunyai lebih sedikit kompetensi. Hal tersebut menunjukkan bahwa karyawan harus diberikan pelatihan yang berkesinambungan untuk memperkaya pengetahuan dan meningkatkan kemampuan (Chong et al., 2011). Berdasarkan hal tersebut, maka dapat dihipotesiskan:

$\mathbf{H}_{2}$ : Terdapat hubungan positif antara program pelatihan kerja dengan kinerja entitas akuntansi.

\subsection{Kinerja Organisasi dan Job Rotation}

Karyawan yang masuk ke dalam divisi yang baru akan membawa pengetahuan, pengalaman, dan keterampilan mereka sebelumnya. Hal tersebut akan menambah nilai sumber daya manusia organisasi/ divisi tersebut. ${ }^{21}$ Melalui program rotasi pekerjaan, bagian dari pengetahuan dan pengalaman yang diperoleh dari departemen sebelumnya dapat dibawa ke departemen yang baru. Dengan demikian, program rotasi pekerjaan memainkan peran penting dalam proses transfer pengetahuan karena akan meningkatkan pertumbuhan pembelajaran/ pengetahuan karyawan dan/ atau organisasi. ${ }^{22}$ Dengan bertambahnya pengetahuan dari program rotasi pekerjaan, kinerja organisasi dapat meningkat, karena organisasi yang mempunyai pengetahuan lebih banyak, akan lebih mempunyai keunggulan kompetitif daripada organisasi dengan sedikit pengetahuan. Berdasarkan hal tersebut, maka dapat dihipotesiskan:

$\mathbf{H}_{3}$ : Terdapat hubungan positif antara program rotasi kerja dengan kinerja entitas akuntansi.

\subsection{Kinerja Organisasi dan KM Technology}

Salah satu pilar penopang implementasi KM dalam sebuah organisasi adalah teknologi. ${ }^{23}$ Teknologi tersebut dapat menghubungkan anggota organisasi dan mempermudah komunikasi baik ke dalam maupun ke luar organisasi. Selanjutnya, teknologi KM yang tersedia dalam organisasi akan

Knowledge Directions, Lexington: Springer, 2003, hlm. 215-251.

21 M.S. Bogdanowicz dan E.K. Bailey, Loc.Cit., hlm. 125-139.

22 Chong et al., Loc.Cit., hlm. 457-512 dan Salleh et al., Loc.Cit., hlm. 164-174.

23 M.A. Stankosky, Advances in Knowledge Management: University Research Toward an Academic Discipline, in Stankosky, M. (Ed.), Creating the Discipline of Knowledge Management - The Latest in University Research. (Oxford: Elsevier, 2005). 
dapat menghubungkan setiap individu dalam organisasi dengan mudah dan cepat sehingga dapat mempermudah proses pengambilan keputusan di dalam organisasi. ${ }^{24}$ Organisasi yang cepat mengambil keputusan dalam pemanfaatan peluang yang ada, akan lebih baik daripada organisasi dengan proses pengambilan keputusan yang lama. Secara otomatis, organisasi tersebut akan mempunyai kinerja yang lebih baik. Berdasarkan hal tersebut, maka dapat dihipotesiskan:

$\mathbf{H}_{4}$ : Terdapat hubungan positif antara ketersediaan teknologi KM dengan kinerja entitas akuntansi.

\subsection{Kinerja Organisasi dan Knowledge Sharing}

Sistem berbagi pengetahuan (knowledge sharing) dapat digambarkan sebagai sistem yang memungkinkan anggota organisasi untuk memperoleh pengetahuan tacit dan explicit dari satu sama lain. ${ }^{25}$ Knowledge sharing dapat meningkatkan kinerja agar lebih baik melalui peningkatan proses pengambilan keputusan dan koordinasi. $^{26}$ Mengelola, mengembangkan, dan memperbarui sistem teknologi informasi akan dapat meningkatkan proses berbagi pengetahuan antar individu di dalam sebuah organisasi. ${ }^{27}$ Selanjutnya knowledge sharing di dalam sebuah organisasi sangat penting untuk melestarikan warisan yang berharga, mempelajari teknik yang baru, memecahkan masalah, menciptakan kompetensi inti, memulai usaha baru, dan akhirnya mendapatkan keunggulan kompetitif. ${ }^{28}$ Selanjutnya, dengan adanya knowledge sharing di

24 Sri Maharsi, "Pengaruh Perkembangan Teknologi Informasi Terhadap Bidang Akuntansi Manajemen". Jurnal Akuntansi \& Keuangan, 2002, Vol. 2. No. 2, hlm. 127 - 137.

25 Irma Becerra Fernandez dan Rajiv Sabherwal, Knowledge Management: System and Process. (London: ME Sharpe, 2010).

26 Sayyed Mohsen Allameh, et al., "Developing Model for Examining the Effect of Tacit and Explicit Knowledge Sharing on Organizational Performance Based on EFQM Approach", The Journal of Science and Technology Policy Management, 2014, Vol.5 No.3, hlm. 255-280.

27 Vera-Munoz, et al., "Enhancing Knowledge Sharing in Public Accounting Firms", Accounting Horizons, 2006, Vol 20. No 2, hlm. 133-155.

28

Zhining Wang, et al., "Knowledge Sharing, Intellectual Capital and Firm Performance", Management Decision, 2014, Vol. 52. No. 2, hlm. 230-258. dalam organisasi, akan dapat meningkatkan kualitas pelayanan yang disediakan oleh pegawai di organisasi sektor publik. ${ }^{29}$ Dengan dasar tersebut, maka dapat dihipotesiskan:

$\mathbf{H}_{5}$ : Terdapat hubungan positif antara proses berbagi pengetahuan dengan kinerja entitas akuntansi.

\section{METODOLOGI PENELITIAN}

\subsection{Populasi dan Sampel}

Populasi dalam penelitian ini adalah entitas akuntansi dengan pengertian sebagaimana tertuang dalam PP No. 71 tahun 2010 yang ada di seluruh Indonesia. Adapun sampel yang diambil adalah entitas akuntansi yang memenuhi 3 kriteria sampel sehingga dapat mencerminkan elemen populasi (Tabel 2), yaitu (1) perwakilan entitas akuntansi di wilayah Indonesia bagian barat, tengah dan timur, (2) perwakilan entitas akuntansi di pulau besar dan pulau kecil, dan (3) perwakilan entitas akuntansi di kota besar dan kota kecil. Sedangkan responden dalam penelitian ini adalah penyusun laporan keuangan entitas akuntansi dengan jumlah total 229 responden.

\subsection{Cara Pengumpulan Data}

Teknik pengambilan sampel dalam penelitian ini adalah purposive sampling. Pengumpulan data dalam penelitian ini menggunakan metode survei dengan kuesioner. Kuesioner dalam penelitian ini didesain dan dikembangkan dari berbagai sumber penelitian terdahulu (Delaney dan Huselid, 1996; Syed-Ikhsan dan Rowland, 2004; Fullwood et al., 2012; dan Salleh et al., 2012). Metode survei dalam penelitian ini dilakukan dengan bantuan teknologi internet (survei online). Cara ini ditempuh dengan alasan lebih dapat menghemat waktu dan tenaga serta biaya mengingat responden berasal dari seluruh wilayah Indonesia.

\subsection{Devisi Operasional dan Pengukuran Variabel}

Kinerja Organisasi adalah indikator yang mengukur seberapa baik sebuah organisasi dalam mencapai tujuan. ${ }^{30}$ Kinerja entitas akuntansi yang dimaksud dalam penelitian ini dikembangkan dari penelitian Delaney dan Huselid (1996) yang

29 G. Anthony Gorry, "Sharing Knowledge in the Public Sector: Two Case Studies", Knowledge Management Research and Practice, 2008, Vol.6. No.2, hlm. 105-111.

30 Li-An Ho, "What Affects Organizational Performance?" Industrial Management \& Data Systems, 2008, Vol. 108. No. 9, hlm. 1234 1254. 
menggunakan dua cara dalam mengukur kinerja organisasi, yaitu melalui kinerja organisasi dan kinerja pasar. Delaney dan Huselid (1996) menggunakan 7 indikator dalam mengukur kinerja organisasi yaitu kualitas pelayanan, inovasi pelayanan, atraksi karyawan, retensi karyawan, kepuasan pelanggan, hubungan manajemen dengan karyawan dan hubungan antar sesama karyawan. Indikator tersebut diukur dengan menggunakan skala likert 5 poin dimulai dengan sangat tidak setuju sampai dengan sangat setuju. ${ }^{31}$

ICT know-how \& skills adalah pengetahuan yang dimiliki organisasi tentang teknologi informasi dan komunikasi baik sebagai explicit knowledge maupun tacit knowledge. ${ }^{32}$ Instrumen ICT know-how \& skills dikembangkan dari penelitian Syed-Ikhsan \& Rowland (2004). Instrumen tersebut diukur dengan menggunakan skala likert 5 poin dimulai dengan sangat tidak setuju sampai dengan sangat setuju.

Pelatihan (training) adalah mentransfer informasi kepada anggota organisasi untuk secara positif meningkatkan efektivitas dan produktivitas organisasi. ${ }^{33}$ Instrumen job training dikembangkan dari penelitian Syed-Ikhsan \& Rowland (2004). Instrumen tersebut diukur dengan menggunakan skala likert 5 poin dimulai dengan sangat tidak setuju sampai dengan sangat setuju.

Rotasi pekerjaan dapat didefinisikan sebagai bekerja di posisi yang berbeda atau dalam situasi yang berbeda pada periode waktu yang diklasifikasikan berdasarkan berbagai pengetahuan individu, keterampilan dan kemampuan karyawan. $^{34}$ Job rotation diukur

31 Jhon T. Delaney dan Mark A. Huselid, "The Impact of Human Resources Management Practices on Perceptions of Organizational Performance", Academy of Management Journal, 1996, Vol. 39. No. 4, hlm. 949 - 969.

32

C. Rosenthal Sabroux dan M. Grundstein, "A Knowledge Management Approach of ICT", Journal of Science, Natural Sciences and Technology, 2008, Vol.24, hlm. 162-169.

33 Shadi Ebrahimi Mehrabani dan Noor Azmi Mohamad, "The Role of 'Training Activities' and 'Knowledge Sharing' in the Relationship between Leadership Development and Organizational Effectiveness", International Conference on Sociality and Economics Development, Singapore, 2011.

34 Shahin Rasouli Saravani dan Badri Abbasi, "Investigating The Influence of Job Rotation on Performance by Considering Skill Variation and dengan menggunakan skala likert 5 poin. Jawaban 1 (sangat tidak setuju) hingga 5 (sangat setuju) menggunakan instrumen penelitian yang digunakan Salleh et al., (2012). ${ }^{35}$

Teknologi yang dimaksud adalah sesuatu hal yang berhubungan dengan berbagai teknologi informasi khusus untuk mendukung atau memungkinkan strategi dan operasi KM, misalnya: email, gudang data/ database, mesin pencari informasi/ search engine, dan lain-lain (Stankosky, 2005). KM Technologies diukur dengan menggunakan skala likert 5 poin. Jawaban 1 (sangat tidak setuju) hingga 5 (sangat setuju) menggunakan instrumen penelitian yang digunakan oleh Syed-Ikhsan dan Rowland (2004).

Berbagi pengetahuan (knowledge sharing) dapat digambarkan sebagai sistem yang memungkinkan anggota organisasi untuk memperoleh pengetahuan tacit dan eksplicit dari satu sama lain. ${ }^{36}$ Knowledge sharing diukur dengan menggunakan skala likert 5 poin. Jawaban 1 (sangat tidak setuju) hingga 5 (sangat setuju) menggunakan instrumen penelitian yang digunakan Fullwood et al., (2012). ${ }^{37}$

\subsection{Analisis Data}

Alat statistik yang digunakan dalam penelitian ini adalah Statistical Package for the Social Science (SPSS) versi 16 dan Analysis of Moment Structures (AMOS) versi 22. SPSS 16 digunakan untuk menguji validitas dan reliabilitas instrumen yang digunakan, sedangkan AMOS 22 digunakan untuk pengujian hipotesis atas model yang diusulkan. Sebelum data siap untuk dianalisis, maka dilakukan proses editing dan coding. ${ }^{38}$ Selain itu perlu dilakukan screening data yaitu proses yang dilakukan setelah coding data untuk menguji kelengkapan data respon dan memastikan tidak ada kesalahan pada saat analisis data. ${ }^{39}$ Screening

Job Satisfaction of Bank Employees". Technical Gazette, 2013, Vol. 20, No. 3, hlm. 473-478.

35 Kalsom Salleh, et al., Loc.Cit., hlm. 164-174.

36 Irma Becerra Fernandez dan Rajiv Sabherwal, Loc.Cit.

37 Roger Fullwood, et al., "Knowledge Sharing among Academics in UK Universities", The Journal of Knowledge Management, 2012, Vol. 17 No. 1, hlm. 123-136.

38 Uma Sekaran dan Roger Bougie, Research Methods for Business: A Skill Building Approach, (New York: John Wiley \& Sons, 2012).

39 Y Anni Aryani, The Effect of Fairness Perception of Performance Measurement in The Balanced Scorecard Environment, Disertasi Ph.D, Tidak 
data meliputi pendeteksian ada tidaknya missing data yang dapat membuat analisis tidak bisa dilakukan. Data yang hilang merupakan permasalahan yang sering dihadapi dalam survei. ${ }^{40}$ Selain itu pendeteksian unengaged responses juga dilakukan, merujuk pada respon yang tidak terpakai dikarenakan terdapat indikasi ketidakseriusan dalam menjawab pertanyaan yang berasal dari responden. ${ }^{41}$ Di samping itu dilakukan juga pendeteksian outliers data. Selain ketiga hal di atas, proses yang harus dilewati adalah deteksi multivariate normality dan multi-collinearity. ${ }^{42}$

Analisis data dilakukan dengan menggunakan prosedur structural equation modelling (SEM). SEM digunakan karena metode ini memiliki keunggulan jika dibandingkan dengan metode statistik multivariat yang lain. Ghozali (2014) mengatakan bahwa SEM memiliki keunggulan karena dalam variabel laten dimasukkan kesalahan pengukuran dalam model. ${ }^{43}$ Lebih lanjut lagi, Allameh et al., (2014) menyatakan bahwa dengan menggunakan SEM, kebaikan model yang diusulkan serta pentingnya hipotesis dalam model yang diusulkan dapat diuji secara bersamaan.

\section{HASIL PENELITIAN}

\subsection{Pengaruh ICT know-how \& skills terhadap kinerja entitas akuntansi di Indonesia}

Hasil uji hipotesis menunjukkan bahwa $\mathrm{H}_{1}$ diterima dengan tingkat signifikansi 0,01. Hal tersebut manandakan bahwa ICT know-how \& skills berpengaruh positif terhadap kinerja entitas akuntansi di Indonesia. Hasil penelitian ini sejalan dengan penelitian yang dilakukan oleh Syed-Ikhsan dan Rowland (2004) yang menyatakan bahwa semakin banyak seseorang diberikan pelatihan menggunakan komputer dan perangkat lunak,

Dipublikasi, University of Victoria, Melbourne, 2009.

40

Rahmat Basuki, "Imputansi Berganda Menggunakan Metode Regresi dan Metode Predictive Mean Matching untuk Menangani Missing Data". Tesis, Tidak Dipublikasikan. Institut Teknologi Surabaya, 2009.

41 James Gaskin, Some General Guidelines for The Order to Conduct Each Procedure, 2015.

42 Imam Ghozali, Aplikasi Analisis Multivariate Dengan Program IBM SPSS 19, (Semarang: Badan Penerbit Universitas Diponegoro, 2011).

43 Imam Ghozali, Model Persamaan StrukturalKonsep dan Aplikasi Dengan Program AMOS 22, (Semarang: Badan Penerbit Universitas Diponegoro, 2014). maka akan semakin banyak pula pemanfaatan pengetahuan dan keterampilan dalam penggunaan teknologi informasi dan komunikasi. Selanjutnya, hal ini akan berimbas pada peningkatan kinerja organisasi secara keseluruhan.

Selain itu Salleh et al., (2012) menambahkan bahwa bukti pengaruh positif dalam penelitian tersebut bukanlah hal yang mengejutkan seiring semakin banyaknya penggunaan sistem pekerjaan yang berbasis komputer. ${ }^{44}$ Atas dasar itulah, dapat diartikan bahwa apabila pegawai yang mempunyai pengetahuan dan keterampilan tentang teknologi informasi dan komunikasi yang semakin baik, maka pegawai tersebut akan semakin mudah menggunakannya dalam penyelesaian pekerjaan sehari-hari yang berbasis komputer. Lebih lanjut, apabila pengetahuan dan keterampilan tentang teknologi informasi dan komunikasi semakin baik, maka hal tersebut akan membuat kinerja entitas akuntansi akan semakin baik pula.

\subsection{Pengaruh job training terhadap entitas akuntansi di Indonesia}

Hasil uji hipotesis menunjukkan bahwa $\mathrm{H}_{2}$ diterima dengan tingkat signifikansi 0,01. Hal tersebut manandakan bahwa job training berpengaruh positif terhadap kinerja entitas akuntansi di Indonesia. Hasil penelitian ini sejalan dengan penemuan Salleh et al., (2012) bahwa job training berpengaruh positif terhadap kinerja organisasi. Selanjutnya Salleh et al., (2012) menyatakan bahwa pegawai atau karyawan, terlebih lagi pegawai fungsional/ profesi, harus mengembangkan kemampuan secara berkala dan konsisten dalam rangka memelihara pengetahuan. Adapun tujuan dari pelatihan kerja (job training) adalah untuk mengembangkan pengetahuan karyawan yang dibutuhkan dalam melaksanakan pekerjaan. ${ }^{45}$

Atas dasar hal tersebut, dapat diartikan bahwa semakin banyak pelatihan kerja yang diterima oleh seorang pegawai, semakin banyak pula pengetahuan yang dimilikinya. Oleh karena itu, pegawai tersebut akan semakin menguasai bidang pekerjaannya. Pekerjaan yang semakin terlaksana dengan baik diharapkan akan dapat meningkatkan kinerja entitas akuntansi di Indonesia.

44 Kalsom Salleh, et al, Loc.Cit., hlm. 164-174.

45 Larry W. Carlile, "Knowledge Management and Training: The Value of Collaboration". Performance Improvement, 2002, Vol. 41. No. 4, hlm. 37- 43 . 


\subsection{Pengaruh job rotation terhadap entitas akuntasi di Indonesia}

Hasil uji hipotesis menunjukkan bahwa $\mathrm{H}_{3}$ ditolak oleh data statistik. Hal tersebut menandakan bahwa job rotation tidak berpengaruh secara signifikan terhadap kinerja entitas akuntansi di Indonesia. Hasil penelitian ini berlawanan dengan penemuan dari Chong et al., (2011) yang menemukan bahwa job rotation berpengaruh positif terhadap kinerja organisasi. Salah satu alasan yang dapat dikemukakan atas hasil penelitian tersebut adalah bahwa pekerjaan di masing-masing divisi atau bagian adalah benarbenar berbeda. Oleh karena itu, job rotation tidak membantu dalam penyelesaian tugas pada divisi yang berbeda (Salleh et al., 2012). Perbedaan pekerjaan tersebut disebabkan adanya job description dan job spesification masing-masing divisi. Sehingga job rotation hanya akan meningkatkan pengetahuan individu yang mengalami rotasi kerja tersebut.

Sebaliknya, pengetahuan kerja di tempat yang lama tidak akan dipakai karena job description dan job spesification sudah berbeda. Rotasi kerja tersebut baru akan dapat meningkatkan kinerja organisasi ketika individu tersebut naik jabatan atau promosi sehingga yang bersangkutan mempunyai kewenangan dalam pengambilan keputusan terhadap divisi-divisi yang dibawahinya. Atas alasan tersebut, dapat diartikan bahwa job rotation tidak berpengaruh terhadap kinerja entitas akuntansi di Indonesia.

\subsection{Pengaruh KM Technology terhadap kinerja entitas akuntansi di Indonesia}

Hasil uji hipotesis menunjukkan bahwa $\mathrm{H}_{4}$ diterima dengan tingkat signifikansi 0,05. Hal tersebut menandakan bahwa KM technology berpengaruh secara positif signifikan terhadap kinerja entitas akuntansi di Indonesia. Hasil ini sejalan dengan penemuan Chong et al., (2011) yang menyatakan bahwa KM technology berpengaruh positif terhadap kinerja organisasi. Lebih lanjut, Chong et al., (2011) mengatakan bahwa teknologi adalah salah satu aspek terpenting yang memfasilitasi keefektivan implementasi KM. Selain itu, hasil penelitian ini juga sejalan dengan penemuan Syed-Ikhsan dan Rowland (2004) yang menyimpulkan bahwa teknologi memainkan peranan kunci dalam pengelolaan pengetahuan oganisasi dan mempunyai kontribusi terhadap kinerja organisasi. Atas dasar hal tersebut, dapat diartikan bahwa semakin baik KM technology yang ada pada suatu organisasi, maka akan dapat meningkatkan kinerja entitas akuntansi di Indonesia.

\subsection{Pengaruh knowledge sharing terhadap entitas akuntansi di Indonesia}

Hasil uji hipotesis menunjukkan bahwa $\mathrm{H}_{5}$ diterima dengan tingkat signifikansi 0,01. Hal tersebut menandakan bahwa knowledge sharing berpengaruh positif terhadap kinerja entitas akuntansi di Indonesia. Hasil ini sejalan dengan penemuan Chong et al., (2011) dan Allameh (2014). Chong et al., (2011) menyatakan bahwa proses knowledge sharing yang efektif merupakan tujuan yang ingin dicapai sebuah organisasi dalam rangka mencapai kinerja organisasi yang lebih baik. Atas dasar hal tersebut, dapat diartikan bahwa apabila knowledge sharing dalam sebuah organisasi semakin berjalan dengan baik, maka akan meningkatkan kinerja entitas akuntansi di Indonesia.

\section{KESIMPULAN DAN SARAN}

Berdasarkan hasil penelitian di atas, dapat ditarik beberapa kesimpulan. Pertama, data statistik membuktikan bahwa ICT know-how \& skills berpengaruh positif terhadap kinerja entitas akuntansi di Indonesia. Oleh karena itu, semakin banyak seorang pegawai mempunyai pengetahuan dan keterampilan tentang teknologi informasi dan komunikasi, maka kinerja entitas akuntansi di Indonesia juga akan semakin baik. Kedua, data statistik membuktikan bahwa job training berpengaruh positif terhadap kinerja entitas akuntansi di Indonesia. Oleh karena itu, semakin banyak seorang pegawai menerima pelatihan kerja, maka kinerja entitas akuntansi di Indonesia juga akan semakin baik. Ketiga, data statistik membuktikan bahwa job rotation tidak berpengaruh terhadap kinerja entitas akuntansi di Indonesia. Alasan yang paling mungkin dari hal tersebut adalah karena pekerjaan pada masingmasing divisi benar-benar berlainan (Salleh et al., 2012) yang disebabkan oleh perbedaan job decription dan job spesification antar masingmasing divisi. Keempat, data statistik membuktikan bahwa KM Technology berpengaruh positif terhadap kinerja entitas akuntansi di Indonesia. Oleh karena itu, semakin tinggi dukungan teknologi, maka kinerja entitas akuntansi di Indonesia juga akan semakin baik. Kelima, data statistik membuktikan bahwa knowledge sharing berpengaruh positif terhadap kinerja entitas akuntansi di Indonesia. Apabila knowledge sharing berjalan dengan semakin baik, maka hal tersebut akan dapat meningkatkan kinerja entitas akuntansi di Indonesia.

Berdasarkan hasil penelitian yang telah dilakukan, maka dapat diajukan beberapa saran. Pertama, sebagaimana $\mathrm{H}_{1}, \mathrm{H}_{2}, \mathrm{H}_{4}$, dan $\mathrm{H}_{5}$ telah terbukti secara statistik, maka hendaknya 
pemerintah, dalam hal ini entitas akuntansi, dapat lebih mengoptimalkan implementasi KM khususnya terkait variabel tersebut sehingga dapat membuat kinerja entitas akuntansi menjadi lebih baik lagi. Kedua, sebagaimana $\mathrm{H}_{3}$ tidak dapat dibuktikan secara statistik, namun bukan berarti hal tersebut tidak penting bagi perbaikan kinerja entitas akuntansi. Rotasi kerja tetap merupakan hal yang penting dan hendaknya tetap dilaksanakan, walaupun hal tersebut baru dapat meningkatkan kinerja organisasi ketika pegawai atau karyawan mendapatkan promosi jabatan. Ketiga, penelitian selanjutnya hendaknya dapat meningkatkan respon rate di atas 30\% untuk dapat lebih mewakili elemen populasi yang ada $\mathrm{di}$ Indonesia. Lebih lanjut, terkait dengan indikator tunggal yang tersisa dalam full model struktural, hendaknya dalam penelitian selanjutnya dapat menambah atau mengembangkan indikator untuk mengukur suatu konstruksi seperti dalam penelitian ini.

\section{IMPLIKASI DAN KETERBATASAN}

Hasil penelitian ini mempunyai beberapa keterbatasan. Pertama, sampel yang digunakan dalam penelitian ini sangat sedikit dengan response rate $27 \%$ (Tabel 1), mengingat elemen populasi adalah entitas akuntansi seluruh Indonesia. Sampel yang sedikit akan mempengaruhi tingkat generalisasi terhadap elemen populasi. Namun, penelitian ini telah dapat memenuhi 3 kriteria sampel yang telah ditetapkan sesuai dengan topografi Indonesia sehingga diharapkan dapat mencerminkan elemen populasi (Tabel 2). Kedua, dalam analisis full model struktural telah didapatkan model yang sesuai dengan data. Akan tetapi, terdapat dua variabel laten yaitu job training dan KM technology yang menyisakan indikator tunggal dalam model tersebut (Gambar 1). Namun, dalam penelitian ini dihadirkan bukti dari analisis regresi berganda dengan data yang sama dan mendapatkan hasil uji hipotesis yang sama (Tabel 3).

\section{PENGHARGAAN (ACKNOWLEDGEMENT)}

Sebagai penutup, penulis mengucapkan terima kasih yang sebesar-besarnya kepada pihak-pihak yang telah membantu dalam penyelesaian penelitian ini.

\section{DAFTAR PUSTAKA (REFERENCES)}

Abdullah, Syukriy dan Asmara, Jhon Andra. (2006). Perilaku Oportunistik Legislatif Dalam Penganggaran Daerah. Simposium Nasional Akuntansi IX. Padang. www.multiparadigma.lecture.ub.ac.id (Diakses Pada 7 Mei 2015).

Allameh, Sayyed Mohsen et al. (2014). “Developing Model for Examining the Effect of Tacit and Explicit Knowledge Sharing on Organizational Performance Based on EFQM Approach". The Journal of Science and Technology Policy Management, Vol.5, No.3, hlm. 255-280.

Anggraini, Normala Dewi. (2013). Pengaruh Praktek Knowledge Management Terhadap Kinerja Organisasi. Skripsi Tidak Dipublikasikan, Universitas Diponegoro, Semarang.

Aryani, Y Anni. (2009). The Effect of Fairness Perception of Performance Measurement in The Balanced Scorecard Environment. Disertasi Ph.D, Tidak Dipublikasikan, University of Victoria, Melbourne.

Aryani, Y Anni et al. (2014). "Kualitas Data Dalam Riset Akuntansi Manajemen dan Keperilakuan: Bukti Empiris dari Metode Survei di Indonesia". Jurnal Akuntansi dan Keuangan, Vol. 16, No. 1, hlm. 1-22.

Basuki, Rahmat. (2009). "Imputansi Berganda Menggunakan Metode Regresi dan Metode Predictive Mean Matching Untuk Menangani Missing Data". Tesis, Tidak Dipublikasikan. Institut Teknologi Surabaya. http://digilib.its.ac.id (Diakses Pada 17 Mei 2015).

Becerra-Fernandez, I. et al. (2004). Knowledge Management - Challenges, Solutions and Technologies. New York: Pearson Prentice Hall.

Bogdanowicz, M.S. dan Bailey, E.K. (2002). "The Value of Knowledge and the Values of the New Knowledge Worker: Generation X in the New Economy". The Journal of European Industrial Training, Vol. 26, No. 2/3/4, hlm. 125-139.

Carlile, Larry. W. (2002). "Knowledge Management and Training: The Value of Collaboration". Performance Improvement, Vol. 41, No. 4, hlm. 37- 43.

Chong, Siong Shoy et al. (2011). "KM Implementation in a Public Sector Accounting Organization: An Empirical Investigation". The Journal of Knowledge Management, Vol. 15, No.3, hlm. 457-512.

Delaney, Jhon T., dan Huselid, Mark A. (1996). “The Impact of Human Resources Management Practices on Perceptions of Organizational 
Performance". Academy of Management Journal, Vol. 39, No. 4, hlm. 949 - 969.

Edwards, J.S., Collier, P.M. dan Shaw, D. (2005). Knowledge Management and Its Impact on The Management Accountant. London: The Chartered Institute of Management Accountants (CIMA)

Evans, Joel R., dan Mathur, Anil. (2005). "The Value of Online Surveys". Internet Research, Vol. 15, No. 2, hlm. 195 - 219.

Evers, H-D., dan Gerke, S. (2005). "Knowledge is Power; Experts A Strategic Group". Working Paper Series 8a. Center for Development Research University of Bonn.

Fernandez, Irma Becerra., dan Sabherwal, Rajiv. (2010). Knowledge Management: System and Process. London: ME Sharpe.

Fullwood, Roger et al. (2012). Knowledge Sharing Among Academics in UK Universities. The Journal of Knowledge Management, Vol. 17, No. 1, hlm. 123-136.

Gaskin, James. (2015). Some General Guidelines for the Order to Conduct Each Procedure. http://statwiki.kolobkreations.com/wiki/G uidelines (Diakses pada 17 Mei 2015).

Ghozali, Imam. (2011). Aplikasi Analisis Multivariate Dengan Program IBM SPSS 19. Semarang: Badan Penerbit Universitas Diponegoro.

Ghozali, Imam. (2014). Model Persamaan Struktural-Konsep dan Aplikasi Dengan Program AMOS 22. Semarang: Badan Penerbit Universitas Diponegoro.

Gorry, G Anthony. (2008). "Sharing Knowledge in The Public Sector: Two Case Studies". Knowledge Management Research and Practice, Vol.6, No.2, hlm. 105-111.

Halim, Abdul., dan Abdullah, Syukriy. (2006). "Hubungan dan Masalah Keagenan di Pemerintah Daerah". Jurnal Akuntansi Pemerintahan, Vol. 2., No. 1, hlm. 53-64.

Hilmi, Amiruddin Zul., dan Martani, Dwi. (2012). "Analisis Faktor-Faktor Yang Mempengaruhi Tingkat Pengungkapan Laporan Keuangan Pemerintah Provinsi". Simposium Nasional Akuntansi XV. Banjarmasin. www.multiparadigma.lecture.ub.ac.id (Diakses pada 7 Mei 2015).

Holsapple, CW., dan Singh, M. (2003). "The Knowledge Chain Model: Activities for Competitiveness". Handbook on Knowledge
Management 2: Knowledge Directions. Lexington KY: Springer, hlm. 215-251.

Ho, Li-An. (2008). "What Affects Organizational Performance?". Industrial Management \& Data Systems, Vol. 108, No. 9, hlm. 1234 1254.

Jensen, Michael C., dan Meckling, William $H$. (1976). "Theory of The Firm: Managerial Behavior, Agency Cost and Ownership Structure". The Journal of Financial Economics, Vol. 3, No. 4, hlm. 305-360.

Latifah, Nurul. (2010). “Adakah Perilaku Oportunistik Dalam Aplikasi Agency Theory di Sektor Publik?". Fokus Ekonomi, Vol 5, No. 2, hlm. 85-94.

Maharsi, Sri. (2000). "Pengaruh Perkembangan Teknologi Informasi Terhadap Bidang Akuntansi Manajemen". Jurnal Akuntansi \& Keuangan, Vol. 2, No. 2, hlm. 127 - 137.

Mehrabani, Shadi Ebrahimi., dan Mohamad, Noor Azmi. (2011). "The Role of 'Training Activities' and 'Knowledge Sharing' in the Relationship between Leadership Development and Organizational Effectiveness". International Conference on Sociality and Economics Development. Singapore.

Ombudsman. 2013. Monitoring Kepatuhan Kementerian dalam Pelaksanaan UU 25 Tahun 2009 tentang Pelayanan Publik.

Peraturan Pemerintah No. 71 Tahun 2010 tentang Standar Akuntansi Pemerintah.

Sabroux, C. Rosenthal dan Grundstein, M. (2008). "A Knowledge Management Approach of ICT". Journal of Science, Natural Sciences and Technology, Vol. 24, hlm. 162-169.

Sadjiarto, Arja. (2000). "Akuntabilitas dan Pengukuran Kinerja Pemerintah". Jurnal Akuntansi \& Keuangan, Vol. 2, No. 2, hlm. $138-150$.

Salleh, Kalsom., dan Ahmad, Syed Noh Syed. (2006). "KM Strategy for E-Government: An Exploratory Study of Local Authorities in Malaysia". Working-Paper, University Technology Mara

Salleh, Kalsom et al. (2012). "Learning and Knowledge Transfer Performance among Public Sector Accountants: an Empirical Survey". Knowledge Management Research and Practice, Vol.10, No. 2, hlm. 164-174. 
Saravani, Shahin Rasouli. dan Abbasi, Badri. (2013). "Investigating The Influence of Job Rotation on Performance By Considering Skill Variation and Job Satisfaction of Bank Employees". Technical Gazette, Vol. 20, No. 3, hlm. 473-478.

Sekaran, Uma dan Bougie, Roger. (2012). Research Methods for Business: A Skill Building Approach. New York: John Wiley \& Sons.

Scott, William R. (2009). Financial Accounting Theory. Edisi Kelima. Toronto: Pearson.

Stankosky, M.A. (2005). "Advances in Knowledge Management: University Research toward An Academic Discipline" in Stankosky, M. (Ed.). Creating The Discipline of Knowledge Management - The Latest in University Research. Oxford: Elsevier.

Syed-Ikhsan, SOS., dan Rowland, Fytton. (2004). "Knowledge Management in Public Organization: A Study on The Relationship Between Organizational Elements and The Performance of Knowledge Transfer". The Journal of Knowledge Management, Vol 8, No 2, hlm. 95-111.

Syed-Ikhsan, SOS., dan Rowland, Fytton. (2004). "Benchmarking Knowledge Management in a Public Organisation in Malaysia". Benchmarking: an International Journal, Vol. 11, No. 3, hlm. 238 - 266.

Undang-undang No. 25 Tahun 2009 tentang Pelayanan Publik.

Vera-Munoz, Sandra C. et al. (2006). "Enhancing Knowledge Sharing in Public Accounting Firms". Accounting Horizons, Vol 20, No 2, hlm. 133-155.

Watts, R.L. dan Zimmerman, J.L. (1990). "Positive Accounting Theory: a Ten Years Perspective". The Accounting Review, Vol. 65, No. 1, hlm. 131 - 156.

Wang, Zhining et al., (2014). "Knowledge Sharing, Intellectual Capital and Firm Performance". Management Decision, Vol. 52, No. 2, hlm. $230-258$.

Whitmore, B. dan Albers, J.A. (2006). "Knowledge Management in an Accounting Organization". The Journal of Knowledge Management Practice, Vol. 7, No. 4, www.tlainc.com/articl123.htm. (Diakses pada 24 Mei 2014).

Zeyn, Elvira. (2011). "Pengaruh Good Governance dan Standar Akuntansi Pemerintahan Terhadap Akuntabilitas Keuangan Dengan Komitmen Organisasi Sebagai Pemoderasi". 


\section{Tabel 1. Rincian Kuesioner Penelitian}

\begin{tabular}{|l|l|c|l|c|c|c|c|c|c|}
\hline $\begin{array}{c}\text { Tahapan } \\
\text { Pengiriman }\end{array}$ & $\begin{array}{l}\text { Kuesioner } \\
\text { Dikirim }\end{array}$ & \multicolumn{2}{|c|}{$\begin{array}{c}\text { Kuesioner } \\
\text { Kembali }\end{array}$} & \multicolumn{2}{c|}{$\begin{array}{c}\text { Kuesioner } \\
\text { Tidak } \\
\text { Lengkap }\end{array}$} & \multicolumn{2}{|c|}{$\begin{array}{c}\text { Kuesioner Tidak } \\
\text { Memenuhi } \\
\text { Syarat }\end{array}$} & \multicolumn{2}{|c|}{$\begin{array}{c}\text { Kuesioner } \\
\text { Memenuhi } \\
\text { Syarat }\end{array}$} \\
& Jumlah & Jumlah & $\%$ & Jumlah & $\%$ & Jumlah & $\%$ & Jumlah & $\%$ \\
\hline Tahap I & 660 & 174 & 26,4 & - & - & 22 & 12,6 & 152 & 87,4 \\
Tahap II & 618 & 175 & 28,3 & - & - & 19 & 10,8 & 156 & 89,2 \\
Total & 1.278 & 349 & 27,3 & - & - & 41 & 11,7 & 308 & 88,3 \\
\hline
\end{tabular}

Sumber: data primer diolah

Tabel 2. Pemenuhan kriteria sampel

\begin{tabular}{|c|c|c|c|}
\hline No & Kriteria sampel & $\begin{array}{c}\text { Jumlah } \\
\text { Responden }\end{array}$ & Persentase \\
\hline 1 & $\begin{array}{l}\text { Zona waktu } \\
\text { a. Indonesia Bagian Barat } \\
\text { b. Indonesia Bagian Tengah } \\
\text { c. Indonesia Bagian Timur }\end{array}$ & $\begin{array}{c}170 \\
47 \\
12\end{array}$ & $\begin{array}{c}74,2 \% \\
20,5 \% \\
5,2 \%\end{array}$ \\
\hline & Total & 229 & $100 \%$ \\
\hline 2 & $\begin{array}{cl}\text { Zona Kepulauan } \\
\text { a. } & \text { Pulau Besar } \\
\text { b. } & \text { Pulau Kecil } \\
\end{array}$ & $\begin{array}{c}172 \\
57 \\
\end{array}$ & $\begin{array}{l}75,1 \% \\
24,9 \% \\
\end{array}$ \\
\hline & Total & 229 & $100 \%$ \\
\hline 3 & $\begin{array}{l}\text { Zona Kota } \\
\begin{aligned} \text { a. } & \text { Kota Besar } \\
\text { b. } & \text { Kota Kecil }\end{aligned}\end{array}$ & $\begin{array}{l}117 \\
112\end{array}$ & $\begin{array}{l}51,1 \% \\
48,9 \%\end{array}$ \\
\hline & Total & 229 & $100 \%$ \\
\hline
\end{tabular}

Sumber: Output SPSS 16

\section{Gambar 1. Full Model Struktural-Akhir}

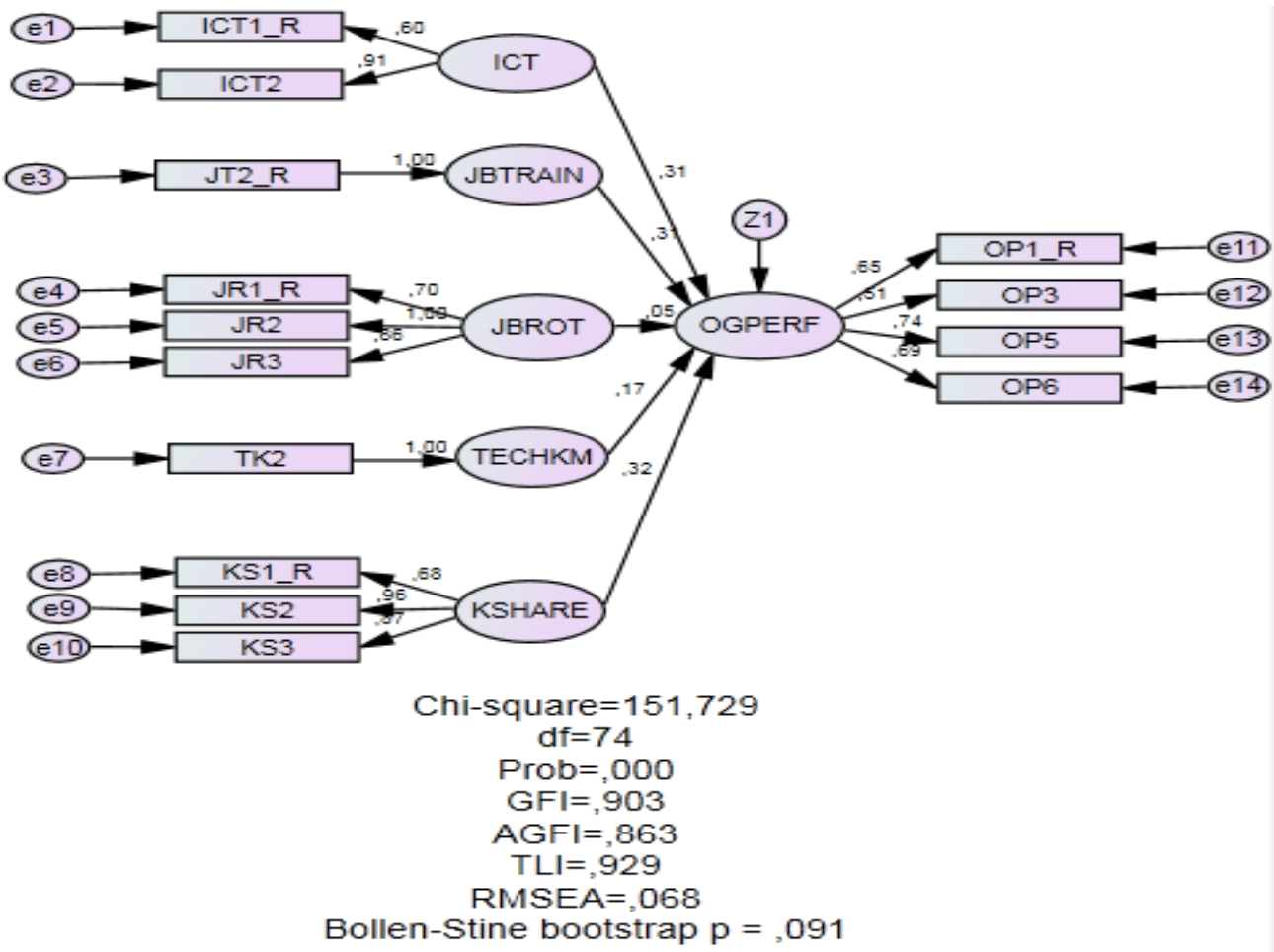


Tabel 3. Nilai Regression Weights Full Model Struktural

\begin{tabular}{|c|c|c|c|c|c|c|c|c|}
\hline \multicolumn{4}{|c|}{ Hipotesis } & Estimate & S.E. & C.R. & $P$ & Keterangan \\
\hline $\mathrm{H} 1$ & OGPERF & $<---$ & ICT & , 167 & ,046 & 3,592 & $* * *$ & Diterima \\
\hline $\mathrm{H} 2$ & OGPERF & $<---$ & JBTRAIN & 156 & ,040 & 3,890 & $* * *$ & Diterima \\
\hline H3 & OGPERF & $<---$ & JBROT & ,031 & ,040 & ,774 & ,439 & Ditolak \\
\hline $\mathrm{H} 4$ & OGPERF & $<---$ & TECHKM & 123 & ,057 & 2,161 &, $031^{* *}$ & Diterima \\
\hline H5 & OGPERF & $<---$ & KSHARE & ,316 & ,085 & 3,695 & $* * *$ & Diterima \\
\hline
\end{tabular}

Sumber: Output AMOS 22

***: Signifikan pada level 0,01

** : Signifikan pada level 0,05 